\title{
Bing-Neel syndrome mimicking a meningioma
}

Andrew Sneed, MD, Philip R. Chapman, MD, and Aparna Singhal, MD

Correspondence

Neurology ${ }^{\circledR}$ 2020;95:838-839. doi:10.1212/WNL.0000000000010834

Dr. Singhal

asinghal@uabmc.edu

Figure Multiplanar MRI of the brain
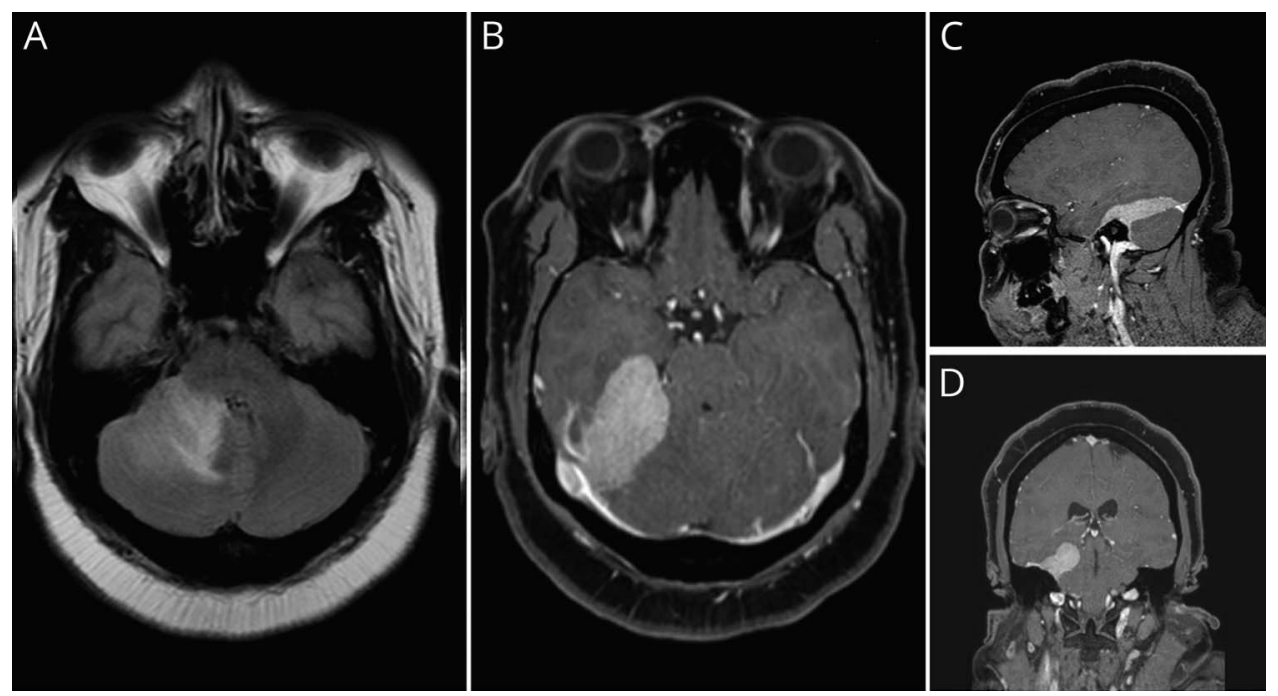

(A) Axial T2 fluid-attenuated inversion recovery MRI sequence demonstrates edema in the right middle cerebellar peduncle/hemisphere. Axial (B), sagittal (C), and coronal (D) postcontrast fat-saturated T1-weighted images demonstrate a focal extraaxial dural based enhancing lesion along the right tentorial leaflet.

A 42-year-old woman presented with progressively worsening right occipital headaches, increased with Valsalva. Brain MRI revealed an enhancing right tentorial leaflet extra-axial mass with adjacent vasogenic edema, which was presumed to be a meningioma (figure). A subtotal resection of the mass was performed and demonstrated pathologic features compatible with lymphoplasmacytic lymphoma (Bing-Neel syndrome), subsequently treated with ibrutinib. Bing-Neel syndrome is a very rare complication of Waldenstrom macroglobulinemia that is characterized by CNS involvement by malignant lymphoplasmacytic cells. ${ }^{1,2}$ The most common imaging features are leptomeningeal or dural infiltration or localized tumoral form with parenchymal involvement. ${ }^{1,2}$

\section{Study funding}

No targeted funding reported.

\section{Disclosure}

The authors report no disclosures relevant to the manuscript. Go to Neurology.org/ $\mathrm{N}$ for full disclosures. 
Appendix Authors

\begin{tabular}{lll}
\hline Name & Location & Contribution \\
\hline $\begin{array}{l}\text { Andrew } \\
\text { Sneed, MD }\end{array}$ & $\begin{array}{l}\text { University of } \\
\text { Alabama at } \\
\text { Birmingham }\end{array}$ & $\begin{array}{l}\text { Data collection, drafting and revision } \\
\text { of manuscript }\end{array}$ \\
\hline $\begin{array}{l}\text { Philip R. } \\
\text { Chapman, }\end{array}$ & $\begin{array}{l}\text { University of } \\
\text { Alabama at }\end{array}$ & Drafting and revision of manuscript \\
\hline $\begin{array}{l}\text { Aparna } \\
\text { Singhal, }\end{array}$ & $\begin{array}{l}\text { University of } \\
\text { MD }\end{array}$ & $\begin{array}{l}\text { Designed and conceptualized study, } \\
\text { data collection, drafting and revision } \\
\text { of manuscript }\end{array}$ \\
\hline
\end{tabular}

\section{References}

1. Malkani RG, Tallman M, Gottardi-Littell N, et al. Bing-Neel syndrome: an illustrative case and a comprehensive review of the published literature. J Neurooncol 2010;96: 301-312.

2. Fitsiori A, Fornecker L, Simon L, et al. Imaging spectrum of Bing-Neel syndrome: how can a radiologist recognise this rare neurological complication of Waldenström's macroglobulinemia? Eur Radiol 2019;29:102-114.

\section{Share Your Artistic Expressions in Neurology 'Visions'}

AAN members are urged to submit medically or scientifically related artistic images, such as photographs, photomicrographs, and paintings, to the "Visions" section of Neurology ${ }^{\circledast}$. These images are creative in nature, rather than the medically instructive images published in the NeuroImages section. The image or series of up to six images may be black and white or color and must fit into one published journal page. Accompanying description should be 100 words or less; the title should be a maximum of 96 characters including spaces and punctuation.

Please access the Author Center at NPub.org/authors for full submission information.

\section{Visit the Neurology ${ }^{\circledR}$ Resident \& Fellow Website}

Click on Residents \& Fellows tab at Neurology.org.

Now offering:

- Neurology ${ }^{\circledR}$ Resident \& Fellow Editorial team information

- "Search by subcategory" option

- E-pearl of the Week

- RSS Feeds

- Direct links to Continuum ${ }^{\circledR}$, Career Planning, and AAN Resident \& Fellow pages

- Recently published Resident \& Fellow articles

- Podcast descriptions

- Blogs by Editors and Resident \& Fellow team members

f Find Neurology ${ }^{\circledR}$ Residents \& Fellows Section on Facebook: facebook.com/AANResidentsAndFellows

Follow Neurology ${ }^{\circledR}$ on Twitter: @GreenJournal \#NeurologyRF

(0) Find Neurology ${ }^{\circledR}$ Residents \& Fellows Section on Instagram: @aanbrain \#NeurologyRF 


\title{
Neurology
}

\author{
Bing-Neel syndrome mimicking a meningioma \\ Andrew Sneed, Philip R. Chapman and Aparna Singhal \\ Neurology 2020;95;838-839 Published Online before print September 15, 2020 \\ DOI 10.1212/WNL.0000000000010834
}

This information is current as of September 15, 2020

\section{Updated Information \& Services}

\section{References}

Citations

Subspecialty Collections

Permissions \& Licensing

Reprints including high resolution figures, can be found at: http://n.neurology.org/content/95/18/838.full

This article cites 2 articles, 0 of which you can access for free at: http://n.neurology.org/content/95/18/838.full\#ref-list-1

This article has been cited by 1 HighWire-hosted articles: http://n.neurology.org/content/95/18/838.full\#\#otherarticles

This article, along with others on similar topics, appears in the following collection(s):

All Oncology

http://n.neurology.org/cgi/collection/all_oncology

Hematologic

http://n.neurology.org/cgi/collection/hematologic

MRI

http://n.neurology.org/cgi/collection/mri

Information about reproducing this article in parts (figures,tables) or in its entirety can be found online at:

http://www.neurology.org/about/about_the_journal\#permissions

Information about ordering reprints can be found online:

http://n.neurology.org/subscribers/advertise

Neurology ${ }^{\circledR}$ is the official journal of the American Academy of Neurology. Published continuously since 1951, it is now a weekly with 48 issues per year. Copyright @ 2020 American Academy of Neurology. All rights reserved. Print ISSN: 0028-3878. Online ISSN: 1526-632X.

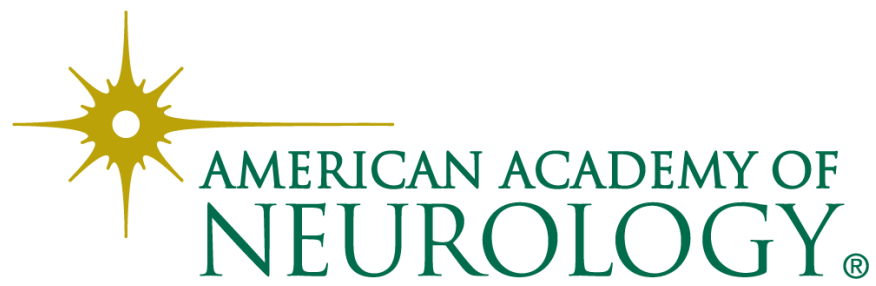

